carrying British species occupy six, and those carrying Continental European species occupy fifteen large cabinets. Most of the plants in this herbarium were collected by White himself on his walks and travels at home and abroad, but numerous additions have from time to time been made by exchange and purchase. The specimens are beautifully mounted, well labelled, carefully catalogued and useful notes and relevant cuttings are frequently attached to the sheets. White was the author of "The Flora of Bristol", published in 1912, which is rightly considered a model of what a county flora should be. His herbarium is, however, of far more than merely local importance. The accuracy and critical nature of his determinations make it of real scientific value and wide general interest. By coming into possession of this herbarium the hortus siccus of the University of Bristol has become one of the four best-equipped university herbaria in England.

\section{Verulamium, 1932}

Excavations at St. Albans in 1932, of which Dr. and Mrs. R. E. Mortimer Wheeler gave an account at the Society of Antiquaries on February 23, have again added to the impressiveness of the prehistoric site and enhanced its importance as a source of knowledge of conditions in Britain immediately before the Roman invasion. The chance discovery in 1932 of a hoard of silver coins a mile north of the Abbey in the dyke running across country from the north of St. Albans in the direction of the village of Sandridge, not only proved the existence of the dyke before the second century A.D., but also led to the determination of the true character of this remarkable work, which is $100 \mathrm{ft}$. broad, 30-40 ft. deep and some five miles long, as a British defensive work extending from the pre-Roman eity at the south-west of St. Albans to prehistoric works, of which the remains are still to be seen at Wheathampstead. Excavations here in the past summer have shown this to be a prehistoric 'city' about a hundred acres in extent, the most remarkable of its kind in the period yet found in Britain. It would appear that this great work was constructed by the Belgic invaders of Britain, who established their headquarters at St. Albans towards the end of the first century B.c. In his account of the past year's exploration of the Roman city, Dr. Wheeler drew a gloomy picture of the social and economic depression, alleviated only by a brief and illusory recovery, which invaded Verulamium as Roman power declined, after a brilliant and perhaps too optimistic efflorescence of prosperity. In the juxtaposition of pre-Roman and Roman on an extensive scale and in the evidence of the varied fortunes of a prolonged Roman occupation, St. Albans, under continued exploration, promises to become one of the most instructive and impressive archæological sites on the fringe of the Roman Empire in the western world.

\section{Federal Council for Chemistry}

IN its report for 1932, the Federal Council for Chemistry refers with regret to the necessary postponement of the ninth International Congress of
Pure and Applied Chemistry and the eleventh conference of the International Union of Chemistry, which were to have been held in Madrid in 1932 . The next meeting of the Union will take place in the spring of 1934 in Madrid, and not in Switzerland, as previously arranged. During the year, the Verein Oesterreichischer Chemiker and the Svenska National Kommitten för Kemie were elected members of the International Union. The report refers to a conference on chemical documentation, held in Paris in October 1932, and indicates that the Federal Council and the Division of Chemistry and Chemical Technology of the U.S. National Research Council are in complete agreement with regard to certain criticisms of the activities of the International Committee dealing with the reform of biochemical nomenclature. The efforts of the British Standards Institution to extend the use of the words "British Standard" to include "chemical substances used in manufactures, photography, or philosophic research and anti-corrosives" were supported by the Federal Couneil. The Board of Trade agreed to the Institution proceeding with an application to register provided that it was in a position to submit support from the appropriate trade association or similar body. A significant passage in the report is as follows: "In October, a Committee consisting of Dr. E. F. Armstrong, Mr. E. R. Bolton, Dr. L. H. Lampitt, Prof. G. T. Morgan, Mr. Emile Mond, Prof. J. C. Philip, Sir William Pope, Mr. J. Davidson Pratt, and Mr. D. Rintoul was appointed 'To consider how the resources of the various bodies concerned with the professional and scientific welfare of chemists can be most economically and efficiently utilised'. This Committee has met on several occasions, and will present, early in 1933, a report on its findings for consideration by the Federal Council." We shall look forward with interest and expectation to the outcome of the deliberations of so representative a committee, which is dealing with a matter of national as well as professional importance.

\section{Photographic Analysis of Explosion Flames}

At the Friday evening discourse at the Royal Institution on February 24, Prof. W. A. Bone discussed "The Photographic Analysis of Explosion Flames". Nowadays the photographic analysis of explosion flames has become an indispensable part of the scientific study of explosions. Prof. Bone described first, with experimental illustrations, how the earlier work of Mallard and Le Chatelier and of Berthelot and Vieille in France, as well as that of H. B. Dixon and his collaborators in Great Britain, during the period 1883-1903, revealed, not only the successive stages in gaseous explosions, but also much about the nature of the final phase of 'detonation' (l'onde explosive) with its intensive chemical action, high constant velocities (one or two metres per second) and shattering effects. Prof. Bone then dealt principally with recent developments in the designing of high-speed cameras by Mr. R. P. Fraser at the Imperial College, South Kensington, where it has now become possible not only to photograph, 